\title{
Monitoring of the Organophosphate Pesticide Chlorpyrifos in Vegetable Samples from Local Markets in Northern Thailand by Developed Immunoassay
}

\author{
Surat Hongsibsong ${ }^{1, *}$, Tippawan Prapamontol ${ }^{1}$, Ting Xu ${ }^{2}$, Bruce D. Hammock ${ }^{3}$, Hong Wang ${ }^{4}$, \\ Zi-Jian Chen ${ }^{4}$ and Zhen-Lin $\mathrm{Xu}^{4}$ (i) \\ 1 Research Institute for Health Science, Chiang Mai University, Chiang Mai 50200, Thailand; \\ tippawan.prapamontol@cmu.ac.th \\ 2 Beijing Key Laboratory of Biodiversity and Organic Farming, College of Resources and Environmental \\ Sciences, China Agricultural University, Beijing 100193, China; xuting@cau.edu.cn \\ 3 Department of Entomology and Nematology and UCD Comprehensive Cancer Center, University of \\ California Davis, Davis, CA 95616, USA; bdhammock@ucdavis.edu \\ 4 Guangdong Provincial Key Laboratory of Food Quality and Safety, College of Food Science, South China \\ Agricultural University, Guangzhou 510642, China; gzwhongd@163.com (H.W.); \\ czj1q2w3e4r5t@163.com (Z.-J.C.); jallent@163.com (Z.-L.X.) \\ * Correspondence: surat.hongsibsong@cmu.ac.th; Tel.: +66-5394-2508
}

Received: 16 May 2020; Accepted: 25 June 2020; Published: 30 June 2020

\begin{abstract}
Chlorpyrifos is an organophosphate pesticide that is wildly used among farmers for crop protection. However, there are concerns regarding its contamination in the environment and food chain. In the present study, an in-house indirect competitive enzyme-linked immunosorbent assay (ic-ELISA) specific for detecting chlorpyrifos is developed and validated against gas chromatography-flame photometric detection (GC-FPD) as the conventional method. The developed ic-ELISA was used for detecting chlorpyrifos residue in vegetable samples. The developed ic-ELISA showed good sensitivity to chlorpyrifos at an $\mathrm{IC}_{50}$ of $0.80 \mu \mathrm{g} / \mathrm{kg}$, with low cross-reactivity to other organophosphate pesticides. The 160 samples were collected from local markets located in the Chiang Rai, Chiang Mai, and Nan provinces in northern Thailand. The positive rate of chlorpyrifos residues in the vegetable samples was $33.8 \%$, with the highest levels found in cucumbers, coriander, and morning glory, at 275, 145 , and $35.3 \mu \mathrm{g} / \mathrm{kg}$, respectively. The highest median levels of chlorpyrifos found in the detected samples were Chinese cabbage $(332 \mu \mathrm{g} / \mathrm{kg})$, cucumber $(146.3 \mu \mathrm{g} / \mathrm{kg})$ and Chinese Kale $(26.95 \mu \mathrm{g} / \mathrm{kg})$. The developed ic-ELISA is suitable for the rapid quantitation of chlorpyrifos residues.
\end{abstract}

Keywords: chlorpyrifos residue; ic-ELISA; GC-FPD; northern Thailand

\section{Introduction}

Chlorpyrifos (O,O-diethyl O-(3,5,6-trichloro-2-pyridinyl) phosphorothioate) is a broad-spectrum organophosphate pesticide, which is the most popular among farmers for protecting their crops by controlling different kinds of pests [1]. It is extremely toxic to a wide range of nontarget aquatic organisms [2]. Additionally, the consumer's health risk is a concern due to presence of residues in fruits and vegetables [3,4], the environment [5,6], and all of the agricultural products [7-9]. The is possible because farmers use high volumes of chlorpyrifos, and thus it has a chance to be detected in many samples and agricultural production in general. Chlorpyrifos can inhibit cholinesterase, i.e., acetyl cholinesterase and butyryl cholinesterase $[10,11]$, and can be cause damage to the central nervous system [12], as well as damage to the sympathetic and parasympathetic nervous systems [13]. 
Moreover, in human epidemiological studies, occupational exposure to chlorpyrifos has been related to neurological and neuro-behavioral deficits, including cognitive impairment [14-18]. Chlorpyrifos also has been shown to produce learning deficits in rats after acute and repeated administration, similar to those induced in Alzheimer's disease (AD) [19]. Therefore, chlorpyrifos has been listed as banned in several countries, including Thailand. However, monitoring still needs to be carried out given its illegal use, because it is a very toxic substance.

Currently, most of the techniques and standard methods for detecting chlorpyrifos are chromatographic based-methods, i.e., liquid chromatography [20], gas chromatography [8,21,22], and mass spectrometric methods [23-25]. Chromatographic-based methods have complicated steps, require skilled technical help, are equipment intensive, require a skilled person, and require a significant amount of time. Therefore, a low number of samples can be analyzed per day, and thus a high number of samples cannot be processed in a short time. Additionally, it also very expensive per sample. Thus, the immunoassay complements instrumental methods in many ways, in particular being more applicable in handling a higher number of samples and field assays [26-30]. The absorbance or color are inversely proportional to compounds in the competitive immunoassay. It is useful to use immunoassay as a tool for detecting chlorpyrifos in a high number of samples for epidemiology studies.

This paper reports on a developed immunoassay for detecting the organophosphate pesticide chlorpyrifos based on mouse polyclonal antibody and its application for the monitoring of chlorpyrifos residues in vegetable samples from the Chiang Mai, Chiang Rai, and Nan provinces in the northern part of Thailand. Analytical parameters, such as the sensitivity, accuracy, and reproducibility, were evaluated, and the results are discussed in comparison with GC-FPD. The residues in vegetable samples were analyzed by using the developed immunoassay as an analytical method.

\section{Materials and Methods}

\subsection{Chemicals and Reagents}

The 3-mercaptopropionic acid, potassium hydroxide $(\mathrm{KOH})$, potassium iodide $(\mathrm{KI})$ hydrochloric acid $(\mathrm{HCl})$, sodium hydroxide $(\mathrm{NaOH})$, bovine serum albumin (BSA), and ovalbumin (OVA) were obtained from Sigma-Aldrich Chemie (Steinheim, Germany). The Bio-Rad protein assay kit was from, BioRad (California, USA). Sodium chloride, tetrabutylammonium iodide (TBAI), disodium hydrogen phosphate, sodium dihydrogen phosphate, potassium dihydrogen phosphate, potassium chloride, sodium carbonate, and citric acid were from Merck (Hohenbrunn, Germany). The organic solvents, i.e., acetonitrile, dimethylformamide, methanol $(\mathrm{MeOH})$, and ethyl acetate, were from J.T. Baker (Pennsylvania, USA). The 3,3' ,5,5'-tetramethylbenzidine (TMB) was from Fluka (Steinheim, Germany), and the tetrahydrofuran (THF), methanol (MeOH) dimethyl formamide (DMF), and dimethyl sulfoxide (DMSO) was from Sigma-Aldrich (Steinheim, Germany). Goat anti-mouse IgG $(\mathrm{H}+\mathrm{L})$ was from Invitrogen (Rockford, USA).

\subsection{Standard Organophosphate Pesticides}

Eighteen organophosphate pesticide (OPs) standards (purity 93-99\%) were purchased from Dr. Ehrenstorfer (Augsburg, Germany) and used for cross-reactivity analysis by immunoassay and analysis by gas chromatography-flame photometric detection (GC-FPD), i.e., chlorpyrifos-methyl (purity 98.7\%), dichlorvos (purity 98.7\%), mevinphos (purity 96.9\%), omethoate (purity 93.4\%), dicrotophos (purity 97.5\%), monocrotophos (purity 98\%), dimethoate (purity 99.3\%), diazinon (purity 98.9\%), parathion-methyl (purity 98.2\%), fenitrothion (purity 98.6\%), malathion (purity 99.4\%), chlorpyrifos (purity 99\%), primiphos-ethyl (purity 99\%), methidathion (purity 98.3\%), prothiophos (purity 95.4\%), profenofos (purity 99\%), ethion (purity 98.8\%), triazophos (purity 98.9\%), ethyl4-nitrophenyl phenylphosphonothioate (EPN) (purity 98.2\%), azinphos-ethyl (purity 99.4\%), and azinphos-methyl (purity 99.6\%). The standard pesticides were prepared in methanol and diluted in $20 \%$ methanol in PBS ( $\mathrm{pH}$ 7.2) before being analyzed by ic-ELISA, and was also stored at $-20{ }^{\circ} \mathrm{C}$ prior to the analysis. 


\subsection{Development of Immunoassay for Detecting Chlorpyrifos}

The immunoassay was developed in accordance to a similar protocol as in previous studies, such as a hapten synthesis, preparation of immunogens and coating antigens, characterizing the polyclonal antibody, and the matrix effect of the sample extract on the antibody [31-34].

\subsubsection{Hapten Synthesis}

The hapten was synthesized by following a previously published method [35,36], with some modification. The haptens were used for preparation of the immunogens and coating antigens as well as the developed immunoassay. The haptens were synthesized as follows in Figure 1:
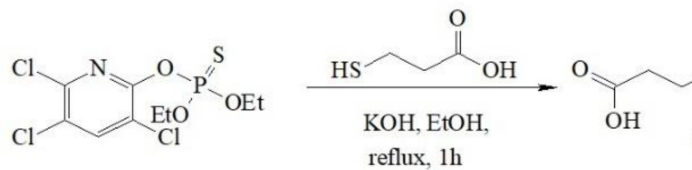

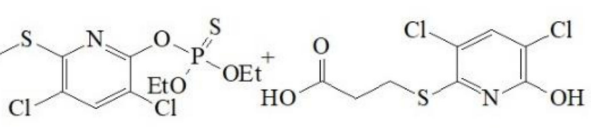

(a)

(b)<smiles>Oc1nc(Cl)c(Cl)cc1Cl</smiles>

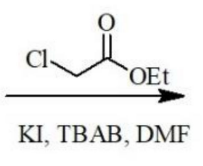<smiles>CCOC(=O)COc1nc(Cl)c(Cl)cc1Cl</smiles>
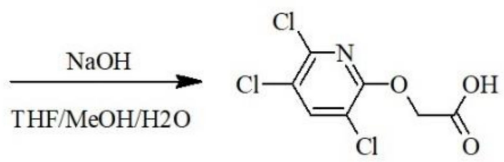

(c)

Figure 1. The synthesis of haptens was performed as previously described [32]. Compounds (a), (b), and (c) were separated by column chromatography.

The structures of the haptens are shown in Figure 1. Synthetic intermediates were analyzed by thin layer chromatography (TLC) and confirmed by ${ }^{1} \mathrm{H}$ - and ${ }^{13} \mathrm{C}$-nuclear magnetic resonance (NMR).

(1) Hapten (a) and (b): To a solution of chlorpyrifos (1.00 g, $2.85 \mathrm{mmol})$ dissolved in ethanol (5 $\mathrm{mL})$, $\mathrm{KOH}(400 \mathrm{mg}, 7.13 \mathrm{mmol}$ ) was added and stirred for $10 \mathrm{~min}$. The resulting solution was treated with 3-mercaptopropanoic acid $(0.30 \mathrm{~mL}, 3.45 \mathrm{mmol})$, and the temperature was raised to $80^{\circ} \mathrm{C}$ and refluxed for $1 \mathrm{~h}$. The solvent was removed under reduced pressure, followed by washing three times with hexane ( $20 \mathrm{~mL}$ each time). The residue was acidified to a $\mathrm{pH}$ of 2 and extracted with $20 \mathrm{~mL}$ of dichloromethane three times. The organic phase was dried over sodium sulfate and concentrated under reduced pressure to give the crude product, which was purified by silica gel column chromatography. The product was mixed between (a) and (b) in a 2:1 ratio with an $83 \%$ yield $(0.68 \mathrm{~g})$. Hapten $(\mathrm{a}),{ }^{1} \mathrm{H}$ NMR $\left(\mathrm{CDCl}_{3}, 400 \mathrm{MHz}\right) \delta 7.65(\mathrm{~s}, 1 \mathrm{H}), 4.33(\mathrm{~m}, 4 \mathrm{H}), 3.41$ $(\mathrm{t}, \mathrm{J}=7.2 \mathrm{~Hz}, 2 \mathrm{H}), 2.90(\mathrm{t}, \mathrm{J}=7.2 \mathrm{~Hz}, 2 \mathrm{H}), 1.41(\mathrm{t}, \mathrm{J}=7.2 \mathrm{~Hz}, 6 \mathrm{H}) ;{ }^{13} \mathrm{C} \mathrm{NMR}\left(\mathrm{CDCl}_{3}, 100 \mathrm{MHz}\right)$ $\delta 176.6,153.6,151.4,138.9,125.0,116.0,66.4,66.3,34.1,25.3,15.9,15.8$ and hapten $(b),{ }^{1} \mathrm{H}$ NMR $\left(\mathrm{CDCl}_{3}, 400 \mathrm{MHz}\right) \delta 7.65(\mathrm{~s}, 1 \mathrm{H}), 4.33(\mathrm{~m}, 4 \mathrm{H}), 3.41(\mathrm{t}, \mathrm{J}=7.2 \mathrm{~Hz}, 2 \mathrm{H}), 2.90(\mathrm{t}, \mathrm{J}=7.2 \mathrm{~Hz}, 2 \mathrm{H}), 1.41$ $(\mathrm{t}, \mathrm{J}=7.2 \mathrm{~Hz}, 6 \mathrm{H}) ;{ }^{13} \mathrm{C} \mathrm{NMR}\left(\mathrm{CDCl}_{3}, 100 \mathrm{MHz}\right) \delta 176.6,153.6,151.4,138.9,125.0,116.0,66.4,66.3$, $34.1,25.3,15.9,15.8$.

(2) Hapten (c): To a solution of chlorpyrifos (1.00 g, $2.85 \mathrm{mmol}$ ) dissolved in 3:2:1 THF/MeOH/water $(5 \mathrm{~mL}), \mathrm{LiOH}(82 \mathrm{mg}, 3.42 \mathrm{mmol})$ was added and stirred for $30 \mathrm{~min}$. The resulting solution was evaporated before adding DMF and then treated with methyl-6-bromohexanoate $(715 \mathrm{mg}$, $3.42 \mathrm{mmol}$ ) and a catalytic amount of TBAI and KI. After refluxing for $1 \mathrm{~h}$, the reaction mixture was allowed to cool down to room temperature before further hydrolysis with $\mathrm{NaOH}$. After completion 
of the reaction, the residue was acidified to a $\mathrm{pH}$ of 2 and extracted with $20 \mathrm{~mL}$ of dichloromethane three times. The extraction phase was dried over sodium sulfate and concentrated under reduced pressure to give the crude product, which was purified by silica gel column chromatography. The product was obtained with a $69 \%$ yield $(0.62 \mathrm{~g}) .{ }^{1} \mathrm{H} \mathrm{NMR}\left(\mathrm{CDCl}_{3}\right) \delta 7.74(\mathrm{~s}, 1 \mathrm{H}, \mathrm{ArH}), 4.92$ $\left(\mathrm{s}, 2 \mathrm{H}, \mathrm{OCH}_{2}\right) ;{ }^{13} \mathrm{C} \mathrm{NMR}\left(\mathrm{CDCl}_{3}, 100 \mathrm{MHz}\right) \delta 171.0,158.6,145.7,140.2,127.2,120.7,65.6$.

\subsubsection{Preparation of the Immunogen and Coating Antigen}

The mixed carboxylic acid hapten was attached to both a protein and an enzyme using the active ester method [37]. Hapten was conjugated to bovine serum albumin (BSA) for immunogen preparation and conjugated to oval albumin (OVA) for coating antigen preparation. The hapten densities of the immunogen and coating antigen were estimated based on mass spectra of ultraviolet spectra to confirm coupling and then calculated [38]. The synthesized immunogen and coating antigen demonstrated qualitative differences between the corresponding carrier protein and conjugate in the UV-Vis spectra, indicating that the hapten had been conjugated to the carrier protein successfully. The estimation of molar absorptivity of the hapten was the same for the free and conjugated forms of the carrier protein. The estimated molar ratio of the immunogen and coating antigen were 12 and 22 , respectively. The protein contents of the hapten-protein conjugates in the dialysates were determined according to the Bio-Rad dye based on the Bradford protein assay.

\subsubsection{Preparation of Polyclonal Antibody (pAb)}

The animals were reared in a clean, standard environment, with a food and water supply. The immunization experimental protocol with animals was performed in accordance with relevant institutional and national guidelines and regulations, and it was approved by the Animal Care and Use Committee, Chiang Mai University (Protocol number: 2561/MC-004). Two BALB/c mice (age 6-8 weeks) were immunized so their immune system would produce polyclonal antibodies by using the prepared immunogen for induction of antibody responses against hapten according to previous studies [38,39]. Two mice were inoculated with $100 \mu \mathrm{g}$ of immunogen dissolved in $10 \mathrm{mM}$ phosphate buffer saline (PBS) and then emulsified with complete Freund's adjuvant (1:1, v/v) injected through the subcutaneous (s.c.) route at multiple sites on the back. Then, they were given three booster immunizations with $100 \mu \mathrm{g}$ of immunogen dissolved in PBS and then emulsified with incomplete Freud's adjuvant $(1: 1, v / v)$ with substitution with Freund's complete adjuvant every two weeks in the same way. Mice were bled from the tail veins before the immunization schedule first and then every week. The serum was separated from the blood by centrifugation and stored in the freezer prior to use for evaluation of the antibody response against hapten by direct ELISA using hapten-OVA as the coating antigen. The serum from a sensitive mouse from the 3rd to 5 th immunization were collected from the tail ( $0.3 \mathrm{~mL}$ each time). After the 6 th immunization for 3 days, the heart blood of the mice was collected. Mice were placed in a deep sleep by saturated carbon dioxide before heart blood collection. All the collected serums were mixed and the pooled serum from the heart blood was prepared (the reciprocal titer about 51,200) and used for further experiments.

\subsubsection{Development of ic-ELISA}

(1) Methanol effect: Methanol is a good solvent for immunoassays and has been used in many previous studies [40-42]. However, the methanol content in PBS may affect the antibody. The methanol contents in PBS were studied by using different concentrations of methanol, i.e., $50 \%, 40 \%, 20 \%$, $10 \%$, and $5 \%$, in PBS as a diluent for chlorpyrifos in several concentrations. The absorbance of each methanol content and $\mathrm{IC}_{50}$ were compared, and due to the good results and no effect from methanol, it was selected as the diluent of the developed immunoassay.

(2) Ionic strength: The ionic strength affected the ic-ELISA, and thus the standard curves of chlorpyrifos were analyzed by using different concentrations of $10 \mathrm{mM}$ PBS at a $\mathrm{pH}$ of 7.0, i.e., $1 \mathrm{x}, 2 \mathrm{x}, 3 \mathrm{x}, 4 \mathrm{x}$, $5 x$, and DI water. 
(3) Indirect Competitive ELISA (ic-ELISA): The ic-ELISA was performed according to the method of Hongsibsong et al. [39]. The concentrations of antibody and coating antigen were optimized by checkerboard titration. The good condition was coating the antigen at $1 \mu \mathrm{g} / \mathrm{mL}$ and a serum dilution at 1:1000. The ic-ELISA was performed by using the optimal concentration as follows. Microtiter plates (Maxisorb, NUNC, Roskilde, Denmark) were coated with $100 \mu \mathrm{L} /$ well of the hapten-OVA $(1 \mu \mathrm{g} / \mathrm{mL})$ as a coating antigen in a carbonate buffer at a $\mathrm{pH}$ of 9.6 and allowed to sit overnight at $4{ }^{\circ} \mathrm{C}$. The plates were washed with PBS plus $0.05 \%$ Tween 20 (PBST) and blocked with $200 \mu \mathrm{L} /$ well of $1 \%$ (w/v) gelatin in PBS at a pH of 7.2. After $1 \mathrm{~h}$ of incubation at room temperature, the plates were washed as described previously. Standards (or samples extracted) were mixed with equal volumes of serum diluted in PBS (1:1000) and pre-incubated for $1 \mathrm{~h}$ at room temperature. The pre-incubated mixture was transferred to the wells $(100 \mu \mathrm{L} /$ well $)$ and incubated for $1 \mathrm{~h}$ at room temperature for competition. Then, the plate was washed by PBST, and $100 \mu \mathrm{L} /$ well of 1:5000 HRP conjugated goat anti-mouse IgG $(\mathrm{H}+\mathrm{L})$ in PBS at a pH of 7.2 was added. After $1 \mathrm{~h}$, the plate was washed, and $100 \mu \mathrm{L}$ of a substrate solution $(0.1 \mathrm{~mL}$ of $1 \%$ $\mathrm{H}_{2} \mathrm{O}_{2}$ and $0.4 \mathrm{~mL}$ of $0.6 \% 3,3^{\prime}, 5,5^{\prime}$-tetramethylbenzidine in dimethyl sulfoxide (DMSO) were added to $25 \mathrm{~mL}$ of citrate-acetate buffer, $\mathrm{pH}=9.6$ ) was added to each well. The plates were stopped with $50 \mu \mathrm{L}$ of $2 \mathrm{~N} \mathrm{H}_{2} \mathrm{SO}_{4}$ and read by an ELISA plate reader (Sunrise, Salzburg, Austria) at $450 \mathrm{~nm}$. The development of a yellow color was inversely proportional to the amount of chlorpyrifos present. The absorbance was calculated for $50 \%$ inhibition by a nonlinear curve fit. The concentration of chlorpyrifos residue was calculated from the standard curve.

(4) Cross-reactivity (CR): The cross-reactivity was studied by ic-ELISA and substitution of the chlorpyrifos standard or sample with an organophosphate pesticide in the same group as chlorpyrifos. Organophosphate pesticide standards were used for cross-reactivity by immunoassay, i.e., chlorpyrifos-methyl, dichlorvos, mevinphos, omethoate, dicrotophos, monocrotophos, dimethoate, diazinon, parathion-methyl, fenitrothion, malathion, chlorpyrifos, primiphos-ethyl, methidathion, prothiophos, profenofos, ethion, triazophos, ethyl 4-nitrophenyl phenylphosphonothioate (EPN), azinphos-ethyl, and azinphos-methyl. The cross-reactivity was determined according to the equation below:

$$
\mathrm{CR}(\%)=\left(\mathrm{IC}_{50} \text { (chlorpyrifos) } / \mathrm{IC}_{50} \text { (interferent) }\right) \times 100 .
$$

(5) Matrix effect of the color from the vegetable sample: Since vegetables have colors, the effects of the various colors of vegetables on the antibody were studied. The green (kale), red (tomato), and white (Chinese cabbage) colors, which are commonly consumed in the Thai community, were evaluated. The vegetable samples were chopped into small pieces and extracted following a previously described method $[4,43]$. The best methanol content was used and the effect of the extraction of each colored vegetable on the antibody was determined. The recovery was computed by spiking chlorpyrifos into a pooled vegetable sample and then extracting before analyzing. The pooled vegetable was prepared from those three kinds of vegetables with no chlorpyrifos residues after analyzing by GC-FPD.

(6) Immunoassay validation: To evaluate the performance of the developed ic-ELISA for organophosphate pesticide chlorpyrifos, three experiments were performed: (1) the recoveries of spiked pooled vegetable samples were measured by ic-ELISA, and the accuracy, precision, limit of detection (LoD), and limit of quantification (LoQ) were reported as the percent of recovery, percent of coefficient of variance $(\% \mathrm{CV}), \mathrm{IC}_{15}$, and $\mathrm{IC}_{20}$, respectively; (2) the applicability of ic-ELISA to detect chlorpyrifos was determined by analyzing 70 blind vegetable samples, and the results were compared against the results from GC-FPD, which is the standard technique with a specific detector for analyzing compounds that include phosphate in their molecule; and (3) the application of the developed ic-ELISA to analyze the organophosphate pesticide chlorpyrifos in vegetable samples. The vegetable samples, i.e., coriander $(n=28)$, yard long bean $(n=23)$, cabbage $(n=17)$, pakchoi $(n=17)$, Chinese cabbage $(n=13)$, morning glory $(n=13)$, cauliflower 
( $n=9)$, spring onion $(n=8)$, broccoli $(n=7)$, chili $(n=7)$, eggplant $(n=6)$, Chinese kale $(n=5)$, cucumber $(n=4)$, and tomato $(n=3)$, were collected from local markets in the Maetang district, Chiang Mai province $(n=28)$; Phaya Mengrai district, Chiang Rai province $(n=77)$; and Muang district, Nan province ( $n=55$ ) - for a total of 160 samples. Five kilograms of each sample was collected in each market; the edible parts were finely chopped and $300 \mathrm{~g}$ was randomly taken for analysis. Then, all of the samples were transferred to the Toxicology Laboratory, Environmental and Health Research Unit, Research Institute for Health Science, Chiang Mai University, and kept in a $-20{ }^{\circ} \mathrm{C}$ freezer prior to analysis.

\subsubsection{Analysis of the Organophosphate Pesticide Residues in the Vegetable Samples}

(1) Sample extraction and clean up: The sample extraction followed the method of $[4,39]$. Briefly, $5 \mathrm{~g}$ of vegetable sample was weighed into a $50 \mathrm{~mL}$ centrifuge tube, followed by the addition of $10 \mathrm{~mL}$ of acetonitrile (high-performance liquid chromatography grade). Two hundred fifty microliters of $5 \mu \mathrm{g} / \mathrm{mL}$ triphenylphosphate (internal standard (IS)) was added and subsequently centrifuged for $5 \mathrm{~min}$ at $2500 \mathrm{rpm}$. The supernatant was transferred to a $50 \mathrm{~mL}$ centrifuge tube with the addition of $6 \mathrm{~g}$ of $\mathrm{MgSO}_{4}$ and $3 \mathrm{~g}$ of $\mathrm{NaCl}$, followed by centrifugation again for $5 \mathrm{~min}$ at $2500 \mathrm{rpm}$. The extract was evaporated to complete dryness using a vacuum rotary evaporator (Buchi, Flawil, Switzerland) with a water bath at 30 to $35^{\circ} \mathrm{C}$ and then reconstituted with $5 \mathrm{~mL}$ of ethyl acetate. One milliliter of ethyl acetate phase was pipetted into 2 dispersive solid-phase extraction tubes and centrifuged for $3 \mathrm{~min}$ at $2000 \mathrm{rpm}$. Finally, the extract was evaporated with a gentle stream of nitrogen at room temperature and subsequently reconstituted in $1.0 \mathrm{~mL}$ of $10 \%$ methanol in $\mathrm{PBS}$ at a $\mathrm{pH}$ of 7.0 for the immunoassay, and another one was reconstituted with $0.5 \mathrm{~mL}$ of ethyl acetate for gas chromatography (GC) analysis.

(2) Gas chromatography-flame photometric detection (GC-FPD): A Hewlett-Packard model 6890 equipped with a flame photometric detector, a capillary column (DB-5MS, $0.25 \mathrm{~mm} \times \mathrm{I}$.D. $\times 30 \mathrm{~m}$ length $\times 0.25 \mu \mathrm{m}$ film thickness (Agilent J \& W column; Agilent Technologies, DE, USA), and a computerized data handling system (GC Chemstation A.10.02; Agilent Technologies, CA, USA) was used. The temperature was $220^{\circ} \mathrm{C}$ for the injection port (splitless mode). The temperature programming of the oven was as follows: initial temperature of $100{ }^{\circ} \mathrm{C}$ for $10 \mathrm{~min}$, first ramp at $15^{\circ} \mathrm{C} / \mathrm{min}$ to $180^{\circ} \mathrm{C}(5 \mathrm{~min})$, second ramp at $5^{\circ} \mathrm{C} / \mathrm{min}$ to $250^{\circ} \mathrm{C} \mathrm{(3} \mathrm{min),} \mathrm{and} \mathrm{the} \mathrm{final} \mathrm{temperature}$ maintained at $290^{\circ} \mathrm{C}$ for $4 \mathrm{~min}$. The carrier gas was $99.999 \%$ helium.

\section{Results and Discussion}

\subsection{Development of the Immunoassay}

Since chlorpyrifos (chlorpyrifos-ethyl) has been imported to Thailand, and in a previous study shown to be the most detected residue in vegetable samples [4], a simpler method was required for detecting chlorpyrifos in a high number of samples. The study developed an in-house immunoassay and applied it for detecting chlorpyrifos in vegetable samples. The hapten was synthesized by following methods previously published $[35,36]$. It was confirmed that the procedure for preparing the hapten could be based on a previous study [35,36], which published a structure of hapten (hapten (a)) that could be used to produce the antibody to chlorpyrifos. The coating antigen prepared by using the same hapten with immunogen did not give good sensitivity for ic-ELISA (data not shown). The polyclonal antibody in the serum from a mouse was used for developing the immunoassay by using the pooled serum from after the 3rd immunization of heart blood $(3.0 \mathrm{~mL})$ because the titer of antibody in the serum samples was equal and used for analyzing the vegetable samples. The dilution of serum at 1:1000 was used for the determination of chlorpyrifos and the validation of the ic-ELISA, along with a good coating antigen, namely, (c)-OVA (compound (c) in Figure 1), which gave the lowest concentration inhibition of chlorpyrifos at an $\mathrm{IC}_{50}$ of $0.80 \mu \mathrm{g} / \mathrm{kg}$. 
Sensitivity and specificity based on the optimized ic-ELISA and the standard curves of chlorpyrifos were developed. The developed ic-ELISA showed high sensitivity to chlorpyrifos with an $\mathrm{IC}_{50}=0.80 \pm 0.56 \mu \mathrm{g} / \mathrm{kg}$. The cross-reactivities (CRs) with dichlorvos, mevinphos, omethoate, dicrotophos, monocrotophos, dimethoate, diazinon, parathion-methyl, fenitrothion, malathion, primiphos-ethyl, prothiophos, ethion, triazophos, ethyl 4-nitrophenyl phenylphosphonothioate (EPN), azinphos-ethyl, and azinphos-methyl at very high concentrations were minimal (>1000 $\mu \mathrm{g} / \mathrm{kg})$. The pAb gave a cross-reactivity with chlorpyrifos-methyl, profenofos, and methidathion at $125 \%$, $14.28 \%$, and $0.28 \%$, respectively. Chlorpyrifos can be determined at concentrations ranging from 20.0 to $2090 \mu \mathrm{g} / \mathrm{kg}$. The $\mathrm{IC}_{50}$ of the present study had both higher [44,45] and lower $[45,46]$ values than previously reported. The specificity of the produced $\mathrm{pAb}$ was good for detecting chlorpyrifos in the sample because it had low cross-reactivity to other OPs, except for chlorpyrifos-methyl, which has no reported use in Thailand (the Office of Agricultural Regulation), and pAb can bind the group of organophosphate pesticides in a smaller number with a high concentration. The hapten with a similar structure to that in the present study gave the same results [45], and this was helpful for developing methods for detecting chlorpyrifos in real samples.

The matrix effect is one of the main factors that restricts the application of immunoassays in pesticide analysis [32,33,47]. In the development of immunoassays for pesticides in vegetables samples, the direct extraction of pesticides from food samples with organic solvents, such as methanol, is commonly used [40-42]. In practice, a dilution of 20-100 times of the methanol extraction should be done to reduce the matrix effect prior to immunoassays. However, the dilution can cause a reduction in the assay sensitivity, and an overlarge dilution would cause inapplicability of the immunoassays. To confirm the applicability based on the developed ic-ELISA, different colored vegetable samples were used as matrix substances. The samples of three colors (green from kale, white from Chinese cabbage, and red from tomato) were used to determine the effect on the assay at different concentrations of 25, 50, and $100 \mu \mathrm{g} / \mathrm{kg}$ compared with $10 \%$ methanol in PBS at a pH of 7.2. The results are shown in Table 1 and confirmed that color had an effect on the binding, but it did not make a significant difference. As color had an effect on the assay, pooled samples were prepared from those three kinds of vegetables with no chlorpyrifos residue after analyzing by GC-FPD. It is good to have used vegetables of different colors, but it does not imply the matrix effects are only due to color. The pooled samples were extracted and used as a matrix for a standard curve for calculating the concentration of chlorpyrifos in the samples. Due to the effect of the organic solvent and the matrix effect, the pooled samples were extracted by using the methods as previously reported. Spiked pooled control samples were extracted between every 20 unknown samples.

Table 1. Effects of the organic solvent, PBS, and matrix effect from the color of vegetables on ic-ELISA.

\begin{tabular}{|c|c|c|c|}
\hline Methanol & $\mathrm{IC}_{50}(\mu \mathrm{g} / \mathrm{kg})$ & PBS, $\mathrm{pH}=7.2$ & $\mathrm{IC}_{50}(\mu \mathrm{g} / \mathrm{kg})$ \\
\hline $50 \%$ & $1.60 \pm 0.60$ & $1 \times$ & $1.40 \pm 0.68$ \\
\hline $25 \%$ & $0.80 \pm 0.12$ & $2 \times$ & $1.20 \pm 0.56$ \\
\hline $10 \%$ & $0.40 \pm 0.24$ & $3 \times$ & $1.80 \pm 0.62$ \\
\hline \multirow[t]{3}{*}{$5 \%$} & $0.52 \pm 0.33$ & $4 \times$ & $2.20 \pm 1.02$ \\
\hline & & $5 \times$ & $4.00 \pm 2.24$ \\
\hline & & DI water & $10.0 \pm 6.78$ \\
\hline \multicolumn{2}{|c|}{ Matrix effect from the colors of vegetable samples } & \multicolumn{2}{|c|}{$\mathrm{IC}_{50}(\mu \mathrm{g} / \mathrm{kg})$} \\
\hline \multicolumn{2}{|c|}{ Tomato } & \multicolumn{2}{|c|}{$0.90 \pm 0.42$} \\
\hline \multicolumn{2}{|c|}{ Kale } & \multicolumn{2}{|c|}{$0.90 \pm 0.38$} \\
\hline \multicolumn{2}{|c|}{ Chinese cabbage } & \multicolumn{2}{|c|}{$1.40 \pm 0.66$} \\
\hline
\end{tabular}




\subsection{The Optimization of ic-ELISA for Detecting Chlorpyrifos}

The optimization parameters are shown in Table 2. The recoveries of chlorpyrifos from the spiked pooled vegetable samples ranged from $95.3 \%$ to $117.8 \%$ (mean $=102.9 \%)$. The precision was reported by the coefficient of variation (CV), and the $\mathrm{CV}$ ranged from $4.6 \%$ to $6.7 \%$, indicating that the developed ic-ELISA can be used for the detection of chlorpyrifos with good reproducibility. The sensitivity was evaluated by determining the limit of detection (LOD) and limit of quantification (LOQ) using the $\mathrm{IC}_{20}$ to $\mathrm{IC}_{80}(0.40$ to $41.8 \mu \mathrm{g} / \mathrm{kg})$. The LOD for the chlorpyrifos at the $\mathrm{IC}_{15}$ was $0.26 \mu \mathrm{g} / \mathrm{kg}$. The LOD and LOQ values were lower than the MRLs established by Codex (Codex Alimentarius Commission, 2019) for vegetables samples. The ability of the developed ic-ELISA was determined: the positive sample was the detected sample by GC-FPD; the negative sample was not detected by GC-FPD; and the positive samples by this method and GC-FPD were 46 and 33 samples, respectively. The results show good correlation with the results from GC-FPD $\left(R^{2}\right.$ linear $\left.=0.910\right)$, where a value of 0.954 was obtained by the Pearson correlation test. The results from ic-ELISA provided overestimated qualitative results, these maybe from the matrix effect and very high sensitivity of the ic-ELISA. The pretreatment of samples could improve the sensitivity because of less dilution [47]. The developed ic-ELISA shows good specificity to chlorpyrifos and chlorpyrifos-methyl, while the previous report showed broad specificity to a group of pesticides, making it unable to quantify a single pesticide within the same sample. The low cross-reactivity to other compounds in the group of OPs led to good specificity to chlorpyrifos and good accuracy to identify the residue in real samples. To validate the result from ic-ELISA by GC-FPD, there was thirteen false positive samples with no false negatives, so that could be applied as both a screening test and quantitative test with a calibration curve. The present study applied the developed ic-ELISA to quantify the single OP, i.e., chlorpyrifos, and the positive sample was confirmed by GC-FPD. The high concentrations above the limit of quantification were diluted and repeated. The concentrations of chlorpyrifos residues in vegetables were calculated against the standard curve (Figure 2) and reported in $\mu \mathrm{g} / \mathrm{kg}$ of vegetable sample. The results of the immunoassay were usually validated with the gold standard technique, i.e., a chromatographic technique $[34,40,48]$.

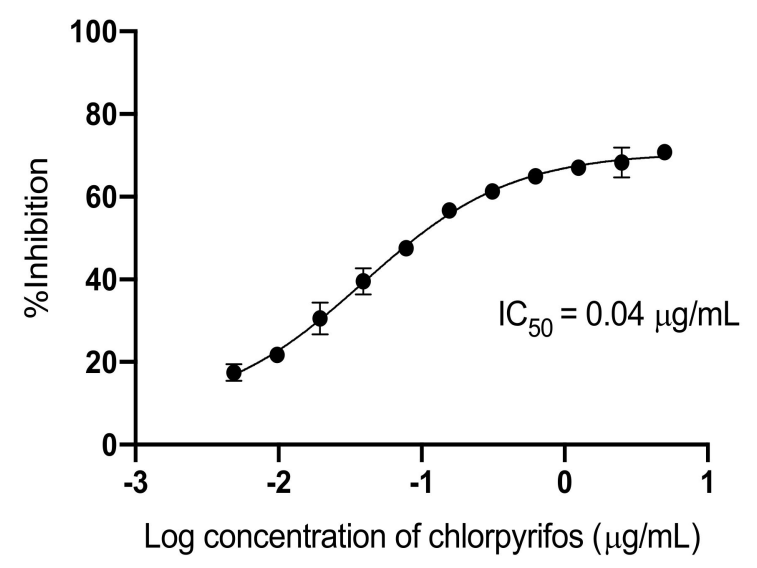

Figure 2. Standard curve of organophosphate pesticide chlorpyrifos by optimized ic-ELISA. The coating antigen was (c)-ova $1 \mu \mathrm{g} / \mathrm{ml}$, and the serum dilution was 1:1000. 
Table 2. Accuracy, precision, limit of detection (LOD), and limit of quantification (LOQ) of the developed ic-ELISA.

\begin{tabular}{ccc}
\hline Parameters & ic-ELISA & GC-FPD \\
\hline LOD,$\mu \mathrm{g} / \mathrm{kg}$ & $0.26\left(\mathrm{IC}_{15}\right)$ & 1.00 \\
$\mathrm{LOQ}, \mu \mathrm{g} / \mathrm{kg}$ & $0.40-41.8\left(\mathrm{IC}_{20}-\mathrm{IC}_{80}\right)$ & 2.00 \\
Precision $(\% \mathrm{CV}, n=4)$ & & \\
$2.00 \mu \mathrm{g} / \mathrm{kg}$ & 4.60 & 2.00 \\
$1.00 \mu \mathrm{g} / \mathrm{kg}$ & 6.70 & 2.58 \\
$0.50 \mu \mathrm{g} / \mathrm{kg}$ & 5.50 & 3.40 \\
Accuracy $(\% \operatorname{Recovery:~} n=5)$ & & \\
$2.00 \mu \mathrm{g} / \mathrm{kg}$ & 95.3 & 114.32 \\
$1.00 \mu \mathrm{gg} / \mathrm{kg}$ & 117.8 & 99.42 \\
$0.50 \mu \mathrm{g} / \mathrm{kg}$ & 95.72 & 97.60 \\
\hline
\end{tabular}

\subsection{Monitoring of Chlorpyrifos Residue in Vegetable Samples from Northern Thailand}

Currently, there are already several studies that indicate that ELISA can be used to analyze agricultural products and food samples after solvent extraction [40,49-51]. The developed ic-ELISA is very useful for analyzing samples in a high number: it is a simple process, using inexpensive equipment, and done in a rapid manner. The conventional methods, such as GC-FPD, used 50 min per sample (one run), while ic-ELISA can analyze 50 samples in one day in approximately $4 \mathrm{~h}$. The developed ic-ELISA exhibited good accuracy and reproducibility, and it is ideally suited as a fast, high-throughput, and low-cost screening test for organophosphate (OP) residues prior to chromatographic analysis. The quality control of ic-ELISA was assessed by analyzing chlorpyrifos intra-batch (analyzing within group of samples, $n=5$ ) and inter-batch (analyzing between groups of samples, $n=10$ ). The results showed good intra-batch $(\% \mathrm{CV}=11.8)$ and inter-batch $(\% \mathrm{CV}=16.3)$, respectively. Table 3 reports the concentration of chlorpyrifos in vegetables surveyed from local markets in three provinces of northern Thailand in 2016, as well as comparison with EU-MRL for assessing the situation of residue chlorpyrifos in vegetable samples from northern Thailand. The frequency that chlorpyrifos residues was found in the vegetable samples was $33.8 \%$, and the highest levels were found in cucumbers, coriander, and morning glory, at 145, 38, and $33 \mu \mathrm{g} / \mathrm{kg}$, respectively. Among the compounds detected, chlorpyrifos was detected in all kinds of vegetable samples. The highest chlorpyrifos level was found in cucumber $(275 \mu \mathrm{g} / \mathrm{kg})$, followed by coriander $(145 \mu \mathrm{g} / \mathrm{kg})$ and Pakchoi $(60.6 \mu \mathrm{g} / \mathrm{kg})$. Previous studies reported chlorpyrifos residues in coriander, Chinese cabbage, broccoli, and Chinese kale [4,52], as well as in mock pakchoi [53], with equal concentrations and detection of chlorpyrifos in the same types of vegetables.

The findings showed that the median concentration of the detected chlorpyrifos for all the vegetables was above the maximum residue limits established by the European Union, except for Thai eggplant and broccoli. No Thai-MRL is yet established for chlorpyrifos residues in vegetables, i.e., water convolvulus, mock pakchoi, and yard long bean. It is concluded that awareness, safety education, and strict regulation of pesticide use is still necessary. 
Table 3. The chlorpyrifos residue in vegetable samples from northern Thailand.

\begin{tabular}{|c|c|c|c|c|c|c|c|c|}
\hline \multirow{2}{*}{$\begin{array}{l}\text { Vegetables } \\
\text { Samples }\end{array}$} & \multirow{2}{*}{$\begin{array}{c}\text { Number of } \\
\text { Samples }\end{array}$} & \multicolumn{2}{|c|}{$\begin{array}{c}\text { Chlorpyrifos Residue } \\
(\mu \mathrm{g} / \mathrm{kg})\end{array}$} & \multirow[t]{2}{*}{ Median } & \multirow[t]{2}{*}{ Min-Max } & \multicolumn{3}{|c|}{$\begin{array}{c}\text { Maximum Residue Limit } \\
(\mu \mathrm{g} / \mathrm{kg})\end{array}$} \\
\hline & & Positive Number & Mean \pm SD & & & Thailand (1) & Codex ${ }^{(2)}$ & $\mathrm{EU}^{(3)}$ \\
\hline Coriander & 28 & 14 & $38.3 \pm 38.4$ & 24.05 & $3.60-145$ & - & - & 10 \\
\hline Yard Long Bean & 23 & 10 & $16.6 \pm 15.5$ & 12.35 & $3.20-56.0$ & - & - & 10 \\
\hline Pakchoi & 17 & 3 & $30.8 \pm 27.8$ & 26.30 & $5.60-60.6$ & - & - & 10 \\
\hline Cabbage & 17 & 2 & $13.4 \pm 0.01$ & 13.45 & $9.00-17.9$ & - & 100 & 10 \\
\hline Chinese Cabbage & 13 & 1 & $332 \pm 0.00$ & 332.3 & 332 & - & 100 & 10 \\
\hline Morning glory & 13 & 3 & $32.8 \pm 2.14$ & 31.7 & $31.5-35.3$ & - & - & 10 \\
\hline Cauliflower & 9 & 3 & $16.4 \pm 9.05$ & 13.00 & $9.60-26.7$ & - & 50.0 & 50 \\
\hline Spring onion & 8 & 6 & $18.6 \pm 8.97$ & 16.45 & $6.10-29.6$ & - & 200 & 10 \\
\hline Broccoli & 7 & 2 & $9.00 \pm 0.42$ & 9.00 & $8.70-9.30$ & - & 2,000 & 10 \\
\hline Chili & 7 & 3 & $24.5 \pm 8.25$ & 23.0 & $17.10-33.4$ & 3000 & - & 10 \\
\hline Thai Eggplant & 6 & 1 & $6.20 \pm 0.00$ & 6.20 & 6.20 & 200 & 100 & 10 \\
\hline Chinese Kale & 5 & 2 & $30.0 \pm 23.8$ & 26.95 & $10.1-43.8$ & - & - & 10 \\
\hline Cucumber & 4 & 2 & $146 \pm 183$ & 146.3 & $16.9-275$ & - & - & 10 \\
\hline Tomato & 3 & 2 & $23.5 \pm 7.50$ & 23.50 & $18.2-28.8$ & - & 2000 & 10 \\
\hline Total & 160 & 54 & $35.3 \pm 58.4$ & 18.40 & $3.2-332$ & - & - & - \\
\hline
\end{tabular}

Note: ${ }^{(1)}$ Thai Food and Drug Administration (2017), ${ }^{(2)}$ Codex Alimentarius Commission (2019), ${ }^{(3)}$ European Commission (2020). 


\section{Conclusions}

The present study shows the ic-ELISA developed from pAb exhibited reliable and high sensitivity for chlorpyrifos detection. In comparison with other ELISA approaches, this developed ELISA exhibited good resilience against organic solvents $(10 \%$ methanol) and a large linear range that spans two orders of magnitude. The developed ELISA was suitable for different levels of chlorpyrifos in samples. The developed inhouse immunoassay method can be used for analyzing chlorpyrifos residue in a high number of vegetable samples, and it is rapid, inexpensive per sample, and can be used for a relevant diversity of samples. The data of chlorpyrifos residues in vegetable samples from the northern part of Thailand detected in many kinds of samples contained chlorpyrifos. Chlorpyrifos residues were the most frequently detected in coriander, with 10 samples $(35.71 \%)$ exceeding the EU-MRL, while spring onion had the highest percent of detection (75\%) exceeding the EU-MRL. A positive sample should be confirmed by standard analytical technique, such as GC-FPD. The contamination levels of chlorpyrifos residues could be considered a possible public health problem because it is the most popular insecticide used among farmers and one of the highest volumes of organophosphate insecticides imported into Thailand.

Author Contributions: Conceptualization, S.H., T.P., T.X., H.W., B.D.H. and Z.-L.X.; methodology, S.H., B.D.H., T.P.; validation, S.H., Z.-J.C., and Z.-L.X.; formal analysis, S.H. and Z.-J.C.; investigation, S.H., T.P., B.D.H., and Z.-L.X.; resources, Z.-L.X. and T.X.; data curation, S.H.; writing-original draft preparation, S.H.; writing-review and editing, S.H., T.P., and B.D.H.; supervision, S.H. and T.P.; project administration, S.H.; funding acquisition, S.H. and T.P. All authors have read and agreed to the published version of the manuscript.

Funding: This research was funded by The Thailand Research Fund (No. TRG6080007), Chiang Mai University, and partial support came from NIEHS/Superfund Research Program P42 ES004699 Biomarkers of exposure to hazardous substances.

Acknowledgments: The authors would like to thank The Thailand Research Fund (No. TRG6080007), Chiang Mai University, and partial support came from NIEHS/Superfund Research Program P42 ES004699 Biomarkers of exposure to hazardous substances. We also offer our thanks to Prof. Mookda Pattarawarapan and Assoc. Prof. Wong Phakhodee, Department of Chemistry, Faculty of Science, Chiang Mai University for the preparation of the haptens.

Conflicts of Interest: The authors declare no conflict of interest.

\section{References}

1. Tawatsin, A.; Thavara, U.; Siriyasatien, P. Pesticides used in Thailand and toxic effects to human health. Med. Res. Arch. 2015, 3, 1-10. [CrossRef]

2. Simon, D.; Helliwell, S.; Robards, K. Analytical chemistry of chlorpyrifos and diuron in aquatic ecosystems. Anal. Chim. Acta 1998, 360, 1-16. [CrossRef]

3. Chen, C.; Qian, Y.; Liu, X.; Tao, C.; Liang, Y.; Li, Y. Risk assessment of chlorpyrifos on rice and cabbage in China. Regul. Toxicol. Pharmacol. 2012, 62, 125-130. [CrossRef] [PubMed]

4. Sapbamrer, R.; Hongsibsong, S. Organophosphorus pesticide residues in vegetables from farms, markets, and a supermarket around Kwan Phayao Lake of Northern Thailand. Arch. Environ. Contam. Toxicol. 2014, 67, 60-67. [CrossRef] [PubMed]

5. Dar, M.A.; Kaushik, G.; Villarreal-Chiu, J.F. Pollution status and bioremediation of chlorpyrifos in environmental matrices by the application of bacterial communities: A review. J. Environ. Manag. 2019, 239, 124-136. [CrossRef]

6. Xiong, J.F.; Guan, Z.; Zhou, G.; Tang, X.; Lv, Y.; Wang, H. Determination of chlorpyrifos in environmental water samples by dispersive liquid-liquid microextraction with solidification of a floating organic drop followed by gas chromatography with flame photometry detection. Anal. Methods 2012, 4, 3246-3250.

7. Yin, P.; Guo, G.Y.; Dai, J.X.; Zhu, L.; Gao, G.W.; Chen, H.P.; Liu, X. Determination of chlorpyrifos and its main metabolite in tea by ultra-high-performance liquid chromatography-tandem mass spectrometry. Chin. J. Anal. Chem. 2019, 47, 306-314.

8. Varela-Martinez, D.A.; Gonzalez-Curbelo, M.A.; Gonzalez-Salamo, J.; Hernandez-Borges, J. Analysis of multiclass pesticides in dried fruits using QuEChERS-gas chromatography tandem mass spectrometry. Food Chem. 2019, 297. [CrossRef] 
9. Ren, Q.; Xia, T. Application of dispersive liquid-liquid microextraction for the analysis of organophosphorus pesticides in Hawthorn (Crataegus Pinnatifida Var. Major) juice samples. Acta Chromatogr. 2016, 28, 403-414. [CrossRef]

10. Garabrant, D.H.; Aylward, L.L.; Berent, S.; Chen, Q.X.; Timchalk, C.; Burns, C.J.; Hays, S.M.; Albers, J.W. Cholinesterase inhibition in chlorpyrifos workers: Characterization of biomarkers of exposure and response in relation to urinary TCPy. J. Expo. Sci. Environ. Epidemiol. 2009, 19, 634-642. [CrossRef]

11. Krenz, J.E.; Hofmann, J.N.; Smith, T.R.; Cunningham, R.N.; Fenske, R.A.; Simpson, C.D.; Keifer, M. Determinants of butyrylcholinesterase inhibition among agricultural pesticide handlers in Washington state: An update. Ann. Occup. Hyg. 2015, 59, 25-40. [PubMed]

12. Basha, P.M.; Poojary, A. Chlorpyrifos induced region-specific vulnerability in rat CNS and modulation by age and cold stress: An interactive study. Neurochem. Res. 2011, 36, 241-249. [CrossRef] [PubMed]

13. Proskocil, B.J.; Bruun, D.A.; Thompson, C.M.; Fryer, A.D.; Lein, P.J. Organophosphorus pesticides decrease M2 muscarinic receptor function in guinea pig airway nerves via indirect mechanisms. PLoS ONE 2010, 5, e10562. [CrossRef] [PubMed]

14. Ismail, A.A.; Wang, K.; Olson, J.R.; Bonner, M.R.; Hendy, O.; Rasoul, G.A.; Rohlman, D.S. The impact of repeated organophosphorus pesticide exposure on biomarkers and neurobehavioral outcomes among adolescent pesticide applicators. J. Toxicol. Environ. Health Part A 2017, 80, 542-555. [CrossRef]

15. Lahouel, A.; Kebieche, M.; Lakroun, Z.; Rouabhi, R.; Fetoui, H.; Chtourou, Y.; Djamila, Z.; Soulimani, R. Neurobehavioral deficits and brain oxidative stress induced by chronic low dose exposure of persistent organic pollutants mixture in adult female rat. Environ. Sci. Pollut. Res. 2016, 23, 19030-19040. [CrossRef]

16. Fiedler, N.; Rohitrattana, J.; Siriwong, W.; Suttiwan, P.; Strickland, P.O.; Ryan, P.B.; Rohlman, D.S.; Panuwet, P.; Barr, D.B.; Robson, M.G. Neurobehavioral effects of exposure to organophosphates and pyrethroid pesticides among Thai children. Neurotoxicology 2015, 48, 90-99. [CrossRef]

17. Ismail, A.A.; Bodner, T.E.; Rohlman, D.S. Neurobehavioral performance among agricultural workers and pesticide applicators: A meta-analytic study. Occup. Environ. Med. 2012, 69, 457-464. [CrossRef]

18. Rohlman, D.S.; Lasarev, M.; Anger, W.K.; Scherer, J.; Stupfel, J.; McCauley, L. Neurobehavioral performance of adult and adolescent agricultural workers. Neurotoxicology 2007, 28, 374-380. [CrossRef]

19. Cassereau, J.; Ferre, M.; Chevrollier, A.; Codron, P.; Verny, C.; Homedan, C.; Lenaers, G.; Procaccio, V.; May-Panloup, P.; Reynier, P. Neurotoxicity of insecticides. Curr. Med. Chem. 2017, 24, 2988-3001. [CrossRef]

20. Ramin, M.; Omidi, F.; Khadem, M.; Shahtaheri, S.J. Combination of dispersive solid-phase extraction with dispersive liquid-liquid microextraction followed by high-performance liquid chromatography for trace determination of chlorpyrifos in urine samples. J. Environ. Anal. Chem. 2019. [CrossRef]

21. Song, S.M.; Huang, H.L.; Chen, Z.J.; Wei, J.; Deng, C.; Tan, H.H.; Li, X.S. Representative commodity for six leafy vegetables based on the determination of six pesticide residues by gas chromatography. Acta Chromatogr. 2019, 31, 49-56. [CrossRef]

22. Yang, Y.H.; Kong, W.J.; Zhao, L.H.; Xiao, Q.; Liu, H.M.; Zhao, X.S.; Yang, M.H. A multiresidue method for simultaneous determination of 44 organophosphorous pesticides in pogostemon cablin and related products using modified QuEchERS sample preparation procedure and Gc-Fpd. J. Chromatogr. B 2015, 974, 118-125. [CrossRef]

23. Zhang, H.T.; West, D.; Shi, H.L.; Ma, Y.F.; Adams, C.; Eichholz, T. Simultaneous determination of selected trace contaminants in drinking water using solid-phase extraction-high performance liquid chromatography-tandem mass spectrometry. Water Air Soil Pollut. 2019, 230. [CrossRef]

24. Garlito, B.; Ibanez, M.; Portoles, T.; Serrano, R.; Amlund, H.; Lundebye, A.K.; Sanden, M.; Berntssen, M.H.G.; Hernandez, F. Lc-Ms/Ms method for the determination of organophosphorus pesticides and their metabolites in salmon and zebrafish fed with plant-based feed ingredients. Anal. Bioanal. Chem. 2019, 411, 7281-7291. [CrossRef] [PubMed]

25. Mondal, R.; Mukherjee, A.; Biswas, S.; Kole, R.K. Gc-Ms/Ms determination and ecological risk assessment of pesticides in aquatic system: A case study in Hooghly River Basin in West Bengal, India. Chemosphere 2018, 206, 217-230. [CrossRef] [PubMed]

26. Liu, J.L.; Zabetakis, D.; Acevedo-Velez, G.; Goldman, E.R.; Anderson, G.P. Comparison of an antibody and its recombinant derivative for the detection of the small molecule explosive 2,4,6-Trinitrotoluene. Anal. Chim. Acta 2013, 759, 100-104. [CrossRef] 
27. Suzuki, C.; Ueda, H.; Mahoney, W.; Nagamune, T. Open sandwich enzyme-linked immunosorbent assay for the quantitation of small haptens. Anal. Biochem. 2000, 286, 238-246. [CrossRef]

28. Wang, K.; Liu, Z.P.; Ding, G.C.; Li, J.; Vasylieva, N.; Li, Q.X.; Li, D.Y.; Gee, S.J.; Hammock, B.D.; Xu, T. Development of a one-step immunoassay for triazophos using camel single-domain antibody-alkaline phosphatase fusion protein. Anal. Bioanal. Chem. 2019, 411, 1287-1295. [CrossRef]

29. Wang, C.M.; Li, X.B.; Liu, Y.H.; Guo, Y.R.; Xie, R.; Gui, W.J.; Zhu, G.N. Development of a mab-based heterologous immunoassay for the broad-selective determination of organophosphorus pesticides. J. Agric. Food Chem. 2010, 58, 5658-5663. [CrossRef]

30. Luo, L.; Song, Y.; Zhu, C.Z.; Fu, S.F.; Shi, Q.R.; Sun, Y.M.; Jia, B.Z.; Du, D.; Xu, Z.L.; Lin, Y.H. Fluorescent silicon nanoparticles-based ratiometric fluorescence immunoassay for sensitive detection of ethyl carbamate in red wine. Sens. Actuators B Chem. 2018, 255, 2742-2749. [CrossRef]

31. Hua, X.D.; Qian, G.L.; Yang, J.F.; Hu, B.S.; Fan, J.Q.; Qin, N.; Li, G.; Wang, Y.Y.; Liu, F.Q. Development of an immunochromatographic assay for the rapid detection of chlorpyrifos-methyl in water samples. Biosens. Bioelectron. 2010, 26, 189-194. [CrossRef] [PubMed]

32. Zhao, F.C.; Hu, C.Y.; Wang, H.M.; Zhao, L.Y.; Yang, Z.Y. Development of a mab-based immunoassay for the simultaneous determination of $\mathrm{O}, \mathrm{O}$-diethyl and $\mathrm{O}, \mathrm{O}$-dimethyl organophosphorus pesticides in vegetable and fruit samples pretreated with QuEChERS. Anal. Bioanal. Chem. 2015, 407, 8959-8970. [CrossRef] [PubMed]

33. Hua, X.D.; Eremin, S.A.; Liu, F.Q.; Wang, M.H. Antibody developments and immunoassays for organophosphorus chemicals: A review. Curr. Org. Chem. 2017, 21, 2640-2652. [CrossRef]

34. Liu, Y.H.; Zhong, D.L.; Shen, D.Y.; Mo, R.H.; Tang, F.B. Determination of four insecticides in bamboo shoot by Quechers-Mspd combined with Lc-Ms/Ms. J. Food Sci. Technol. Res. 2014, 20, 563-569. [CrossRef]

35. Manclus, J.J.; Montoya, A. Development of an enzyme-linked immunosorbent assay for 3,5,6-Trichloro-2-Pyridinol.1. Production and characterization of monoclonal antibodies. J. Agric. Food Chem. 1996, 44, 3703-3709. [CrossRef]

36. Manclus, J.J.; Primo, J.; Montoya, A. Development of a chlorpyrifos immunoassay using antibodies obtained from a simple hapten design. J. Agric. Food Chem. 1994, 42, 1257-1260. [CrossRef]

37. Peeters, J.M.; Hazendonk, T.G.; Beuvery, E.C.; Tesser, G.I. Comparison of four bifunctional reagents for coupling peptides to proteins and the effect of the three moieties on the immunogenicity of the conjugates. $J$. Immunol. Methods 1989, 120, 133-143. [CrossRef]

38. Hongsibsong, S.; Prapamontol, T.; Suphavilai, C.; Wipasa, J.; Pattarawarapan, M.; Kasinrerk, W. Production of monoclonal antibody to acaricide dicofol and its derivatives. Hybridoma 2010, 29, 495-500. [CrossRef]

39. Hongsibsong, S.; Wipasa, J.; Pattarawarapan, M.; Chantara, S.; Stuetz, W.; Nosten, F.; Prapamontol,, T. Development and application of an indirect competitive enzyme-linked immunosorbent assay for the detection of $\mathrm{p}, \mathrm{p}^{\prime}$-DDE in human milk and comparison of the results against GC-ECD. J. Agric. Food Chem. 2012, 60, 16-22. [CrossRef]

40. Vasylieva, N.; Ahn, K.C.; Barnych, B.; Gee, S.J.; Hammock, B.D. Development of an immunoassay for the detection of the phenylpyrazole insecticide fipronil. Environ. Sci. Technol. 2015, 49, 10038-10047. [CrossRef]

41. Piao, Y.Z.; Kim, Y.J.; Kim, Y.A.; Lee, H.S.; Hammock, B.D.; Lee, Y.T. Development of ELISAS for the class-specific determination of organophosphorus pesticides. J. Agric. Food Chem. 2009, 57, 10004-10013. [CrossRef] [PubMed]

42. Zhang, Q.; Sun, Q.; Hu, B.S.; Shen, Q.; Yang, G.; Liang, X.; Sun, X.; Liu, F.Q. Development of a sensitive ELISA for the analysis of the organophosphorous insecticide fenthion in fruit samples. Food Chem. 2008, 106, 1278-1284. [CrossRef]

43. Hongsibsong, S.; Sapbamrer, R. Removal of organophosphorus pesticide residues in leaf and non-leaf vegetables by using ozone water. Chiang Mai J. Sci. 2018, 45, 1759-1769.

44. Gabaldon, J.A.; Maquieira, A.; Puchades, R. Development of a simple extraction procedure for chlorpyrifos determination in food samples by immunoassay. Talanta 2007, 71, 1001-1010. [CrossRef]

45. Kim, Y.A.; Lee, E.H.; Kim, K.O.; Lee, Y.T.; Hammock, B.D.; Lee, H.S. Competitive immunochromatographic assay for the detection of the organophosphorus pesticide chlorpyrifos. Anal. Chim. Acta 2011, 693, 106-113. [CrossRef]

46. Brun, E.M.; Garces-Garcia, M.; Banuls, M.J.; Gabaldon, J.A.; Puchades, R.; Maquieira, A. Evaluation of a novel malathion immunoassay for groundwater and surface water analysis. Environ. Sci. Technol. 2005, 39, 2786-2794. [CrossRef] 
47. Xu, Z.L.; Deng, H.; Deng, X.F.; Yang, J.Y.; Jiang, Y.M.; Zeng, D.P.; Huang, F.; Shen, Y.D.; Lei, H.T.; Wang, H.; et al. Monitoring of organophosphorus pesticides in vegetables using monoclonal antibody-based direct competitive ELISA followed by Hplc-Ms/Ms. Food Chem. 2012, 131, 1569-1576. [CrossRef]

48. Zhao, F.C.; Wang, H.M.; Han, X.; Yang, Z.Y. Development and comparative study of chemosynthesized antigen and mimotope-based immunoassays for class-specific analysis of $\mathrm{O}, \mathrm{O}$-dimethyl organophosphorus pesticides. Sci. Rep. 2016, 6, 37640. [CrossRef]

49. Li, M.; Sheng, E.; Cong, L.; Wang, M. Development of immunoassays for detecting clothianidin residue in agricultural products. J. Agric. Food Chem. 2013, 61, 3619-3623. [CrossRef]

50. Mitake, S. Development of immunoassay test kit "Smartassay Series" for pesticide analysis. In Horiba Technical Reports; Horiba: Fukuoka, Japan, 2012; Volume 16.

51. Vasylieva, N.; Barnych, B.; Rand, A.; Inceoglu, B.; Gee, S.J.; Hammock, B.D. Sensitive immunoassay for detection and quantification of the neurotoxin, tetramethylenedisulfotetramine. Anal. Chem. 2017, 89, 5612-5619. [CrossRef]

52. Prasopsuk, J.; Iwai, C.B. Risk assessment of pesticide residues in organic waste in Northeast Thailand. Int. J. Environ. Rural Dev. 2011, 2, 5.

53. Wanwimolruk, S.; Phopin, K.; Boonpangrak, S.; Prachayasittikul, V. Food safety in Thailand 4: Comparison of pesticide residues found in three commonly consumed vegetables purchased from local markets and supermarkets in Thailand. PeerJ 2016, 4, e2432. [CrossRef] [PubMed]

(C) 2020 by the authors. Licensee MDPI, Basel, Switzerland. This article is an open access article distributed under the terms and conditions of the Creative Commons Attribution (CC BY) license (http://creativecommons.org/licenses/by/4.0/). 